\title{
CLINICAL AND EPIDEMIOLOGICAL PROFILE OF ELDERLY PATIENTS WITH CHAGAS DISEASE FOLLOWED BETWEEN 2005-2013 BY PHARMACEUTICAL CARE SERVICE IN CEARÁ STATE, NORTHEASTERN BRAZIL
}

Laíse dos Santos PEREIRA(1), Erlane Chaves FREITAS(1), Arduína Sofia Ortet de Barros Vasconcelos FIDALGO(1), Mônica Coelho ANDRADE(1), Darlan da Silva CÂNDIDO(1), José Damião da SILVA FILHO(1), Vladimir MICHAILOWSKY(2), Maria de Fátima OLIVEIRA(1) \& José Ajax Nogueira QUEIROZ(2)

\begin{abstract}
SUMMARY
By controlling the transmission of Chagas disease, the challenge of providing assistance to millions of infected patients that reach old age arises. In this study, the socioeconomic, demographic and comorbidity records of all elderly chagasic patients followed at the Pharmaceutical Care Service of the Chagas Disease Research Laboratory were assessed. The information related to the clinical form of the disease was obtained from medical records provided by the Walter Cantídio University Hospital. The profile of the studied population was: women (50.5\%); mean age of 67 years; retired (54.6\%); married (51.6\%); high illiteracy rate (40.2\%); and family income equal to the minimum wage $(51.5 \%)$. The predominant clinical forms of Chagas disease were cardiac $(65.3 \%)$ and indeterminate (14.7\%). The main electrocardiographic changes were the right bundle branch block (41.0\%), associated or not with the anterosuperior left bundle branch block (27.4\%). The average number of comorbidities per patient was $2.23 \pm 1.54$, with systemic arterial hypertension being the main one found (67.0\%). It was found that the elderly comprise a vulnerable group of patients that associate aging with cardiac and/or digestive disorders resulting from the evolution of Chagas disease and other comorbidities, which requires special attention from health services to ensure more appropriate medical and social care.
\end{abstract}

KEYWORDS: Chagas disease; Elderly; Cardiac form; Comorbidities.

\section{INTRODUCTION}

Chagas disease (CD) is a chronic infection caused by the protozoan Trypanosoma cruzi and transmitted to humans by blood-sucking insects (kissing bugs) of the family Reduviidae and subfamily Triatominae ${ }^{30,47}$. As a result of the success achieved in the efforts to control vectorial and transfusional transmissions of $\mathrm{CD}$ during the last decades, the challenge of providing assistance to millions of infected in its chronic phase arises ${ }^{59}$. It is estimated that about 18 million people are infected with the disease, particularly in Latin America, with about 21,000 deaths reported each year ${ }^{63}$.

Several studies have demonstrated a progressive reduction of seropositivity for $\mathrm{CD}$ in young age groups and the consequent increase of the prevalence of infection among older individuals ${ }^{3,6,34}$. It is believed that a large proportion of individuals with $\mathrm{CD}$ are either already in old age, or will become elderly in the near future ${ }^{21}$.

It is essential that importance be given to the association between $\mathrm{CD}$ and the aging process of its carriers. Along with the decline that occurs with advancing age ${ }^{21}$, added to cardiac and/or digestive disorders that result from the progression of $\mathrm{CD}$, this group of patients is susceptible to other chronic diseases of advanced age, such as ischemic heart disease, diabetes mellitus, hypertension and arthrosis ${ }^{41}$. This increases the morbidity and worsens the quality of life of the individuals that age in this unfavorable condition con $^{3,31,38,64}$.

These associations lead to a significant demand for health services and drugs, predisposing this vulnerable population to many risks such as polypharmacy ${ }^{21,43,60}$. The scarcity of research on CD among the elderly contrasts with the importance of this disease in this age group ${ }^{34}$.

Therefore, the aim of this study was to better understand the clinical and epidemiological profile of elderly chagasic patients from a Pharmaceutical Care Service reference in the State of Ceará, since these aspects of this population in particular should receive attention, given that medical and social care is one of the main challenges of this neglected disease in Brazil $^{3,15}$.

\section{MATERIAL AND METHODS}

This was a descriptive cross-sectional survey conducted in the Pharmaceutical Care Service on the chagasic patients of the Laboratory of Research in CD at the Federal University of Ceará (LPDC/UFC). This

(1) Departamento de Análises Clínicas e Toxicológicas, Faculdade de Farmácia, Universidade Federal do Ceará, Fortaleza, Ceará, Brazil.

(2) Departamento de Patologia e Medicina Legal, Faculdade de Medicina, Universidade Federal do Ceará, Fortaleza, Ceará, Brazil.

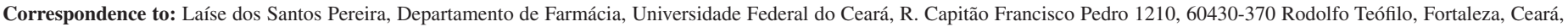
Brasil. Phone: 55.85.33668265. E-mail: laisesantospereira@ hotmail.com 


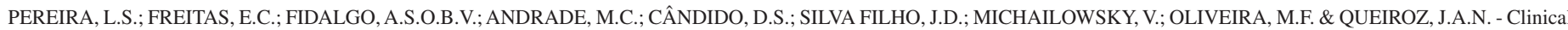
and epidemiological profile of elderly patients with Chagas disease followed between 2005-2013 by pharmaceutical care service in Ceará State, Northeastern Brazil. Rev. Inst. Med. Trop. Sao Paulo, 57(2): 145-52, 2015.

service is linked to the Cardiology Outpatient Unit of the Walter Cantídio University Hospital (HUWC), responsible for the clinical diagnosis of patients with CD. Once diagnosed, the patient is referred to this Service to perform the drug treatment for $\mathrm{CD}$.

The records of all patients followed in the Service during the period of July 2005 (date of commencement of this Service) to June 2013 were analyzed, totaling eight years. The study included elderly patients of both sexes selected according to the criteria of the Brazilian Institute of Geography and Statistics (IBGE), which sets the age as 60 years or over $^{29}$. Patients whose medical records were not available for consultation at HUWC or presented insufficient data for the proposed objectives and analyses were excluded from the clinical evaluation of the study.

The following variables: gender, age, occupation, marital status, education, family income, place of origin, comorbidities, medication use and symptoms related to $\mathrm{CD}$, were obtained from records filed in the LPDC obtained by interview during the first contact with the patient on the Service. The clinical information related to $\mathrm{CD}$, the records of radiological studies of the esophagus, colon and heart, and electrocardiographic results were obtained through medical records filed in the HUWC.

To characterize the clinical form of the disease, the following criteria were used in accordance with the literature ${ }^{6,11}$ :

I - Cardiac form: Symptomatic or asymptomatic individuals with electrocardiographic (ECG) changes suggestive of cardiac involvement and/or registration of cardiomegaly (detected by chest X-ray) in the medical record;

II - Digestive form: Individuals with test results in their medical records (esophagogram or endoscopy and/or barium enema or colonoscopy) compatible with megaesophagus and/or megacolon, and/ or history of surgery for megaesophagus and/or megacolon.

III - Indeterminate form: Asymptomatic individuals presenting normal electrocardiogram (ECG), without registration of cardiomegaly in the medical records, and no changes in X-ray compatible with megaesophagus and/or megacolon;

IV - Mixed Form: Individuals presenting association between cardiac and digestive form.

This study was approved by the Research Ethics Committee of the HUWC in June 2012 under protocol number 031.05.12.

For statistical analysis, the GraphPad Prism Program (version 6.0) was used. For values with normal distribution, the " $\mathrm{t}$ " Student test was used, whereas the Mann Whitney test was used for values that did not show normal distribution. To investigate possible associations between variables, the Fisher's exact test was used. A significance level of $p<$ 0.05 was adopted.

\section{RESULTS}

From the total of 411 patients followed at this Service between July 2005 and June 2013, 97 (23.6\%) were individuals aged over 60 years.
A progressive increase in the percentage of elderly patients relative to the total number of patients enrolled in the Service has been observed during its eight years of activity. Between July 2005 and June 2007, only two elderly patients were registered among 59 patients $(3.4 \%)$. In the period from July 2007 to June 2009, there were 16 elderly patients from a total of 80 patients $(20.0 \%)$. In the following period, July 2009 to June 2011,105 patients were enrolled, 22 of whom were elderly (21.0\%). And finally between July 2011 and June 2013, 167 patients were registered and 57 were elderly (34.1\%) (Fig. 1). Comparing the percentage of elderly patients corresponding to the first four years of activity of the service $(12.9 \%)$ with the subsequent four years $(29.0 \%)$, there was a significant increase in this percentage $(p=0.003)$.

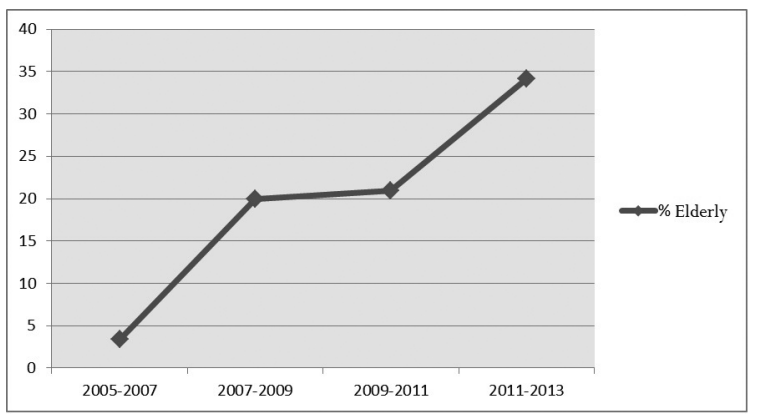

Fig. 1 - Biannual increase of the percentage of elderly patients with Chagas disease enrolled in the Pharmaceutical Care Service in Ceará State during its eight years of activity $(n=97)$.

Regarding the sociodemographic characteristics, it was found that most patients were women $(50.5 \%) ; 70.1 \%$ were aged between 60 and 69 years; the mean age was $66.9 \pm 6.5$ years; $54.6 \%$ were retired, and among those still working, the main occupation registered was farming $(55.0 \%) ; 49.5 \%$ had not finished elementary school and a high percentage of illiteracy was found $(40.2 \%) ; 51.5 \%$ had a monthly income equal to the minimum wage; and most $(51.6 \%)$ were married .

With respect to the place of origin, 81 patients $(83.5 \%)$ were reported to reside in the countryside of the state of Ceará and $16(16.5 \%)$ were from the capital, Fortaleza. The main inland towns cited by the patients as places of origin were: Quixeré $(18 ; 18.5 \%)$, Jaguaruana $(16 ; 16.5 \%)$, Russas $(14 ; 14.4 \%)$ and Limoeiro do Norte $(13 ; 13.4 \%)$, municipalities located in the Low Jaguaribe Microregion, in Jaguaribe Valley. The other cities mentioned by patients as places of residence are shown in Figure 2.

When asked how they were diagnosed with $\mathrm{CD}$, the majority of patients $(30.9 \%)$ reported that the presentation of symptoms of the cardiac and/or digestive form led them to seek medical care; $27.8 \%$ were diagnosed by routine serological tests; $19.6 \%$ by electrocardiographic changes characteristic of $\mathrm{CD}$; and $6.2 \%$ through blood donation.

In terms of symptoms related to $\mathrm{CD}, 18.5 \%$ of patients reported being asymptomatic, while $81.5 \%$ reported at least one symptom attributable to $\mathrm{CD}$. The most frequently reported cardiac symptoms were chest pain $(42.3 \%)$, dyspnea $(36.1 \%)$, palpitations $(23.7 \%)$, fatigue $(17.5 \%)$, dizziness $(7.2 \%)$ and syncope $(6.2 \%)$. The most cited digestive symptoms were constipation $(36.1 \%)$ and dysphagia (23.7\%).

Two patients were excluded from the evaluation of the clinical form of $\mathrm{CD}$ due to insufficient information in their medical records (loss of 


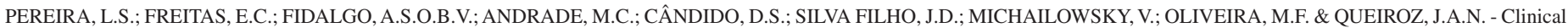
and epidemiological profile of elderly patients with Chagas disease followed between 2005-2013 by pharmaceutical care service in Ceará State, Northeastern Brazil. Rev. Inst. Med. Trop. Sao Paulo, 57(2): 145-52, 2015.

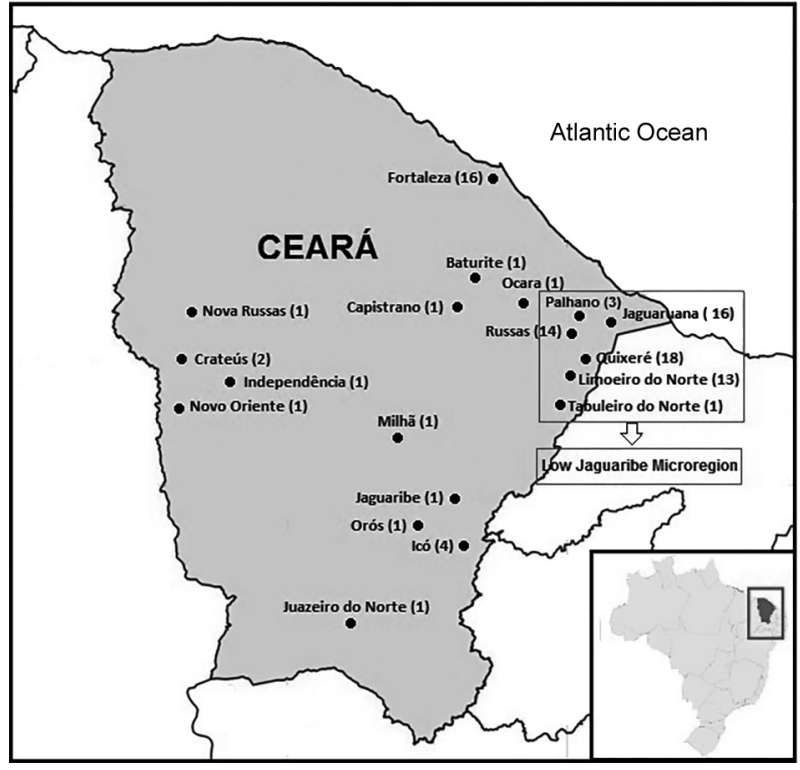

Fig. 2 - Place of origin of the elderly patients with Chagas disease in the state of Ceará $(n=97)$

2.1\%). Thus, the 95 analyzed patients had the following distribution according to the clinical form: predominance of the cardiac form $(65.3 \%)$, followed by indeterminate form $(14.7 \%)$, mixed $(13.7 \%)$ and digestive (6.3\%) (Fig. 3).

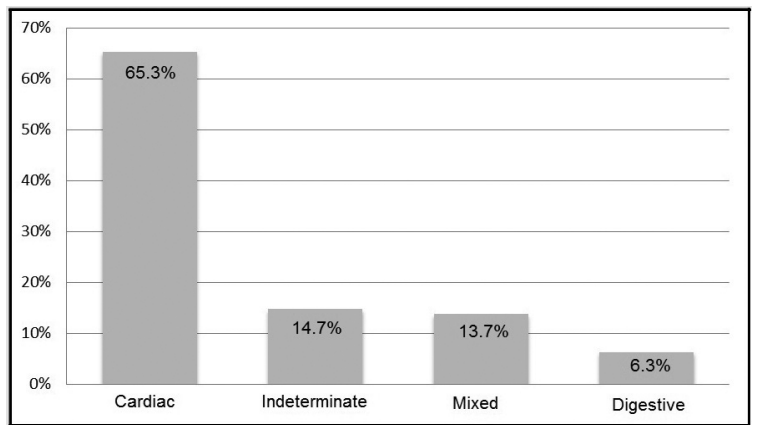

Fig. 3 - Clinical forms of the Chagas disease of elderly patients followed at the Pharmaceutical Care Service in Ceará State $(\mathrm{n}=95)$.

Among patients with the mixed form, the association between cardiac form and chagasic megacolon $(61.5 \%)$ was dominant, followed by cardiac form in association with megaesophagus $(30.8 \%)$. One patient $(7.7 \%)$ presented the cardiac form associated with both megacolon and megaesophagus. As for those ranked in the digestive form, four patients $(66.7 \%)$ suffered from megacolon while two $(33.3 \%)$ had megaesophagus.

Among these 95 patients, 75 (77.3\%) had at least one change in ECG characteristics of CD. The major electrocardiographic abnormalities found among elderly patients with the isolated cardiac form of $\mathrm{CD}$ or associated with the digestive form (mixed form) are described in Table 1.

With regard to the existence of other diseases associated with $\mathrm{CD}$, only $13.4 \%$ of patients reported no comorbidities, while $86.6 \%$ reported having at least one concomitant disease to $\mathrm{CD}$. The average number of
Table 1

Electrocardiographic changes found in elderly patients with Chagas disease followed at the Pharmaceutical Care Service in Ceará State $(\mathrm{n}=95)$

\begin{tabular}{lcc}
\hline Electrocardiographic changes & $n$ & $\%$ \\
\hline Right bundle branch block (RBBB) & 39 & 41.0 \\
Anterosuperior left bundle branch block (ASDB) & 26 & 27.4 \\
Changes in ventricular repolarization (CVR) & 16 & 16.8 \\
Ventricular extrasystole (VES) & 13 & 13.9 \\
Low voltage of the limb leads (LVLL) & 06 & 6.3 \\
First-degree atrioventricular block (AVB) & 05 & 5.3 \\
Sinus bradycardia & 05 & 5.3 \\
Electrically inactive area (EIA) & 04 & 4.2 \\
Left bundle branch block (LBBB) & 03 & 3.2 \\
Atrial fibrillation (AF) & 03 & 3.2 \\
Left ventricular hypertrophy (LVH) & 03 & 3.2 \\
\hline
\end{tabular}

comorbidities per elderly patient in this study was $2.23 \pm 1.54$ (CI: 1.92 2.54 ) and the main ones reported are described in Table 2. In relation to changes possibly resulting from the evolution of $\mathrm{CD}, 12.4 \%$ of the followed patients had arrhythmia and $8.2 \%$ congestive heart failure (CHF).

Table 2

Comorbidities associated with Chagas disease in elderly patients followed in the Pharmaceutical Care Service in Ceará State $(n=97)$

\begin{tabular}{lcc}
\hline Comorbidities & $n$ & $\%$ \\
\hline Systemic Arterial Hypertension (SAH) & 65 & 67.0 \\
Dyslipidemia & 31 & 31.9 \\
Dyspepsia & 16 & 16.5 \\
Diabetes Mellitus & 14 & 14.4 \\
Osteoporosis & 11 & 11.3 \\
Depression & 06 & 6.2 \\
Arthritis & 06 & 6.2 \\
Ischemic Heart Disease & 04 & 4.1 \\
Asthma & 04 & 4.1 \\
Rheumatism & 04 & 4.1 \\
Hypothyroidism & 03 & 3.1 \\
Cerebrovascular Accident (CVA) & 03 & 3.1 \\
Chronic Renal Failure (CRF) & 03 & 3.1 \\
\hline
\end{tabular}

With respect to medication use, $84.5 \%$ of the subjects reported continuous use of at least one drug. The average number of medications per patient was $3.12 \pm 2.44$ (CI: $2.63-3.61)$. The therapeutic agents most frequently used were diuretics $(45.4 \%)$, angiotensin-converting enzyme inhibitors (ACEI) $(36.1 \%), \alpha$ and $\beta$-blockers (21.6\%), anticoagulants 


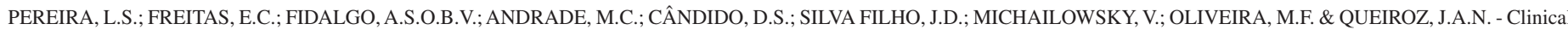
and epidemiological profile of elderly patients with Chagas disease followed between 2005-2013 by pharmaceutical care service in Ceará State, Northeastern Brazil. Rev. Inst. Med. Trop. Sao Paulo, 57(2): 145-52, 2015.

(21.6\%), statins (17.5\%), antacids/anti-ulcer (16.5\%), anxiolytic/sedative $(15.5 \%)$, antagonists of the angiotensin receptor $1(14.4 \%)$, antidiabetic agents (13.4\%), antiarrhythmic drugs (12.4\%), calcium channel blockers (10.3\%), laxatives $(8.2 \%)$, drugs to treat osteoporosis $(8.2 \%)$ and positive inotropic agents $(7.2 \%)$.

\section{DISCUSSION}

The present study demonstrated a significant increase in the number of elderly patients enrolled in the Pharmaceutical Care Service throughout its eight years of activity. This finding corroborates the study of GUARIENTO et al. ${ }^{22}$, which showed a progressive increase in the percentage of elderly patients enrolled in the Outpatient Unit of the Group for Studies into Chagas Disease (GEDoCh) at the Clinical Hospital of Campinas State University (UNICAMP) over 25 years (1980-2005).

The increased prevalence of CD among individuals with older age can be attributed to: the reduction in the incidence of this disease in Brazil, resulting from the success of the vector and transfusion transmission control campaigns; the improving social status of the population with housing improvement in endemic regions; and greater efficiency in diagnostic and therapeutic approaches ${ }^{16,21,62}$. Furthermore, the Brazilian population in general has experienced major changes in its demographic profile with substantial aging of the population as a result of the fall in the rate of mortality associated with the rapid and marked decline of the fecundity rate ${ }^{28}$.

The rise of an elderly population with CD deserves special attention, since this association may have particularities that need further investigation ${ }^{9}$, making the studies regarding the clinical aspects of $\mathrm{CD}$ in this geriatric age group a priority ${ }^{15}$. Due to the fact that the elderly population has specific and peculiar characteristics, the healthcare for this group of patients requires a more careful evaluation from health professionals $^{51}$, so that a clinical diagnosis of $\mathrm{CD}$ in the elderly is not confused with other diseases most prevalent in these individuals, such as dilated cardiomyopathy, ischemic heart disease, heart disease by arterial hypertension and cancer of the esophagus ${ }^{9}$.

This study allowed the identification of a sociodemographic standard for chagasic elderly patients followed in the Pharmaceutical Care Service. The following groups were predominant in the population: women, patients between 60 and 69 years old, retirees, married individuals, and those with a poor education and low income. A very similar profile was observed by ALVES et al. ${ }^{4}$ when 90 elderly chagasic patients from the Outpatient Clinic GEDoCh of the Hospital of UNICAMP were evaluated. It is known that the epidemiological profile of a patient with $\mathrm{CD}$ is that of an adult, from a rural region and with a low level of schooling, demonstrating the close relationship of the disease with underdevelopment and poverty ${ }^{14}$.

It is important to emphasize the high percentage (40.2\%) of illiterate patients that were detected in this study. ALVES et al. ${ }^{4}$ reported in their study that this reality is a reflection of the socioeconomic conditions of chagasic patients who have few social opportunities, low wages and limited education.

Despite the small difference, the percentage of elderly chagasic women $(50.5 \%)$ was higher than the percentage of men $(49.5 \%)$ in the present study. In other studies, also involving elderly patients, the female sex was predominant compared to the male $\operatorname{sex}^{3,4,22}$. GUARIENTO et $a l .{ }^{22}$ point out that this aspect may be related to worse prognosis of CD associated with the male sex. This fact is well evidenced in the literature, where the male sex acts as a risk factor for worse outcomes among chronic carriers of this disease so that men tend to die younger, not reaching old age ${ }^{49,52}$. Furthermore, a study showing the situation of the elderly in Brazil documented a higher mortality of men in relation to women ${ }^{35}$. This is what the literature on gerontology refers to as the feminization of aging, a result of increased life expectancy among women at 60, 70 and 80 years old ${ }^{32,48}$.

Regarding the place of origin, it was observed that most of the elderly patients $(67.0 \%)$ were from the Low Jaguaribe Microregion. The Jaguaribe Valley is a region in Ceará that has always aroused interest among researchers as to the epidemiological importance of $\mathrm{CD}$. The pioneering studies were performed by $\mathrm{ALENCAR}^{2}$ and demonstrated high rates of human infection and capture of triatomines in this region. More recent studies have focused on the detection of seroprevalence in municipalities of the Lower Juaguaribe Microregion such as Limoeiro do Norte $^{18}$, Jaguaruana ${ }^{6}$ and Russas ${ }^{13}$. According to BORGES-PEREIRA et $a l^{6}{ }^{6}$, from the literature about CD in Ceará, the municipality of Jaguaruana and neighboring regions have always been in the group of areas with the highest prevalence of $T$. cruzi infection. These same authors found that $52.9 \%$ of the seropositive patients for CD were over 50 years old and there were no individuals younger than 16 years old. This reduction of seropositivity in younger age groups and the consequent increase in the prevalence of the disease among older individuals is a result of the success of measures to control vectorial transmission. Thus, the active search in this region has led to the diagnosis of patients with CD mainly in the elderly age group, which is possibly a result of vectorial infection acquired in the past. Once diagnosed, these patients are referred to reference services in Fortaleza, including the Pharmaceutical Care Service of patients with CD of the LPDC, a fact that may explain the high prevalence of elderly patients from this region.

The predominant clinical form of CD among patients included in this study was the cardiac, followed by the indeterminate, mixed and digestive forms. For mixed and digestive forms, the incidence of megacolon was higher than that of megaesophagus. These findings are consistent with other studies in the literature, where the cardiac form is prevalent among the elderly chagasic $\mathrm{i}^{3,4,22}$.

The high percentage of cardiac form found in this study $(65.3 \%)$ can be explained because it was performed with patients aged over 60 years. Such an interpretation is associated with the fact that an older age is related to a more severe clinical form of $\mathrm{CD}$ with impairment of cardiac function ${ }^{21}$. This phenomenon has been documented in the literature, showing that the evolutionary character of $\mathrm{CD}$ reflects the progressive aging of its carriers, as the disease transmission has been interrupted $^{16}$.

SILVA et al. ${ }^{58}$ have shown that the age variable acts as a risk factor associated with the development of Chagas heart disease. They observed that patients over 60 years old were three times more likely to have heart disease when compared to those aged 50-59 $(\mathrm{OR}=2.89,95 \% \mathrm{CI}=$ 1.09-7.61). This finding seems plausible, since the rate of conversion of chronic indeterminate to cardiac form, although small, is time dependent. 


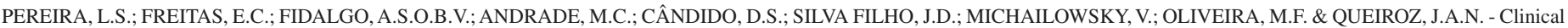

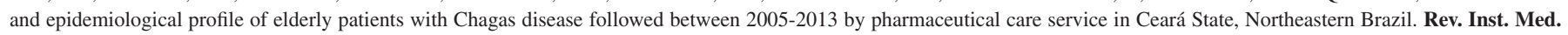
Trop. Sao Paulo, 57(2): 145-52, 2015.

According to PIANCASTELI ${ }^{50}$, the true prevalence of the digestive form is not well known or may be underestimated due to the greater propaedeutic difficulty and, in the case of colonopathy, to the lack of consensus on the interpretation of results. Moreover, it is important to mention that patients included in this study come from the Cardiology Clinic of the HUWC and are not always followed by a gastroenterologist, which may lead to an underestimation of the actual percentage of patients with the digestive form of the disease.

The patients classified as indeterminate (14.7\%) constitute a group characterized by a long asymptomatic period (which may last a lifetime), with no clinical, electrocardiographic and radiological manifestations, and their diagnosis is based on positive serology and/or parasitology $\mathrm{y}^{11,12}$. In most cases, chagasic individuals with this clinical form are unaware of the presence of infection and show good prognosis in the medium and long terms. However, they must still be regularly monitored, since about $2-5 \%$ of these patients annually advance to the cardiac and/or gastrointestinal forms ${ }^{39}$.

The pathogenesis of Chagas heart disease involves mechanisms such as direct injury caused by $T$. cruzi; autoimmunity induced by $T$. cruzi antigens, with consequent destruction of myocytes, sympathetic and parasympathetic ganglia; microvascular disease and neurogenic mechanisms with sympathetic and parasympathetic dysfunction, inducing the inflammatory process and fibrosis ${ }^{26}$. In severe cases the disease evolves to $\mathrm{CHF}$, cardiomegaly, arrhythmias, conduction block of the electrical stimulus, thromboembolic events, ischemic stroke and sudden death ${ }^{11,54}$. Among individuals who develop this clinical form of the disease, a significant group becomes candidate for the use of artificial heart devices, such as defibrillators and pacemakers, with CD being the major cause of the implantation of such devices ${ }^{53}$.

The presence of electrocardiographic changes is a fundamental element in the characterization of significant cardiac involvement in $\mathrm{CD}^{11}$. The electrocardiographic findings in this study are in agreement with the literature. ALMEIDA et al. ${ }^{3}$, when evaluating 61 elderly chagasic patients, found ECG abnormalities in $85.2 \%$, the most prevalent of which were: ASDB (41.0\%), RBBB (32.8\%), VES (22.9\%) and CVR $(11.5 \%)$. The most prevalent conduction disorder in the sample of the present study was the RBBB (41.0\%), associated or not to ASDB, data also convergent with the literature. NETTO et al. ${ }^{44}$ also studied elderly patients and confirmed the RBBB as the most frequent alteration in the chagasic group. According to the Brazilian Consensus on $\mathrm{CD}^{11}$, electrocardiographic changes characteristic of CD include: RBBB with or without ASDB, VES, sinus bradycardia with a cardiac frequency lower than $40 \mathrm{bpm}, \mathrm{AVB}$ of $2^{\text {nd }}$ degree or total, CVR, presence of EIA, sinus node dysfunction, $\mathrm{AF}$ and $\mathrm{LBBB}$.

With respect to the existence of chronic diseases concomitant with $\mathrm{CD}$, the high percentage $(86.6 \%)$ of patients that reported at least one comorbidity associated with $T$. cruzi infection in this study was expected, since, according to the literature, the elderly have higher morbidity rates than other groups of patients ${ }^{61,64}$.

A similar result was found by ALVES et al. ${ }^{4}$, where the average number of comorbidities associated with $\mathrm{CD}$ by elderly patients was $2.8 \pm 1.8$, the most prevalent of which were: $\mathrm{SAH}(56.7 \%)$, osteoporosis (23.3\%), osteoarthritis $(21.2 \%)$, dyslipidemia (20\%), ischemic heart disease, diabetes mellitus and dyspepsia in equal proportions (10\%), as well as $\mathrm{CHF}$ and hypothyroidism, which had an incidence of $7.78 \%$ each.

Statistics show that the main cause of morbidity and mortality among elderly Brazilians is cardiovascular diseases and the main ones include: CVA, CHF, coronary heart disease, hypertrophic cardiomyopathy, valvular disease (aortic stenosis and mitral valve disease), arrhythmia and $\mathrm{SAH}^{36,37,55,64}$. In a survey based on the analyses of data from the Ministry of Health, it was found that in Maringá - PR, between 1970 and 1990, there was a significant increase in the number of deaths associated with SAH (119\%) and an increased risk of death associated with cardiovascular disease in both sexes as age advances ${ }^{42}$. In the present population, the most frequent cardiovascular diseases were SAH (67\%), CHF (8.2\%), ischemic heart disease $(4.1 \%)$ and CVA $(3.1 \%)$. It is important to note that hypertension and dyslipidemia, major comorbidities found in this study with prevalence rates of $67 \%$ and $31.9 \%$ among elderly patients with $\mathrm{CD}$, are important factors for the development of ischemic heart disease and cerebrovascular disease ${ }^{4,37}$.

Previous publications have shown that $\mathrm{SAH}$ is the most common cardiovascular disease in chagasic populations s, $^{3,46,57}$ and that it has a higher prevalence in patients aged over 50 years, showing a cumulative effect between the two pathologies ${ }^{5,24}$. Greater myocardial damage was observed by GUARIENTO et al. ${ }^{20}$ in patients with this combination of diseases. They determined that more severe forms of heart disease occurred in chagasic patients suffering from SAH than in those who did not have SAH. Also, high levels of heart damage from SAH in elderly chagasic patients who died and underwent necropsy have been observed ${ }^{45}$.

There is still scarce data in the literature about concomitant hypertension and $\mathrm{CD}$. Research related to this association is relevant due to the known presence of parasympathetic nervous system involvement in $\mathrm{CD}$, which determines a higher sympathetic activity, leading to a probable influence on the genesis of hypertension in these patients ${ }^{25,26}$. Some authors ${ }^{23,24}$ point out trypanosomiasis pathophysiology as a contributing factor to high blood pressure, also indicating that $50 \%$ of individuals with this combination of pathologies are over 45 years old and already have $\mathrm{CHF}$ to some degree.

GURGEL et al. ${ }^{25}$, when correlating the frequency of SAH in chronic CD carriers with age, observed that the 225 chagasic and hypertensive patients had a median age distribution of 55 years with significant differences of hypertensive degree between age groups for both sexes ( $p<0.001$ for females and $p<0.05$ for males). Higher levels of blood pressure were found in elderly chagasic patients, particularly females, showing the association of both diseases in advanced age groups.

Thus, it is plausible to suppose that there is a higher risk of death among aging chronic carriers of $\mathrm{CD}$, and that this fact is associated with a higher incidence of cardiovascular disease (particularly the higher incidence of SAH $)^{4}$. Moreover, it cannot be forgotten that the physiological changes resulting from the cardiovascular aging process contribute to the deterioration of cardiac function, leading to a functional decline ${ }^{33,40}$.

The cardiac complications resulting from the process of evolution of Chagas heart disease are important causes of hospitalization and increase mortality associated with clinical decompensation ${ }^{10}$. BOZELLI et al. ${ }^{7}$ 


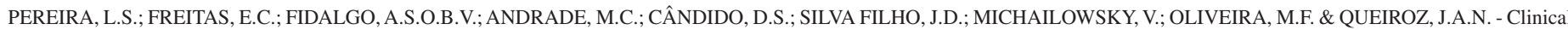
and epidemiological profile of elderly patients with Chagas disease followed between 2005-2013 by pharmaceutical care service in Ceará State, Northeastern Brazil. Rev. Inst. Med. Trop. Sao Paulo, 57(2): 145-52, 2015.

studied the medical records of 95 patients diagnosed with $\mathrm{CD}$ treated at the University Hospital of Maringa (HUM). They observed that the mean age of patients treated in the inpatient service $(61.2$ years \pm 12.8$)$ was significantly higher than that of the outpatient unit (50.1 years \pm 12.5$)$. In most cases, hospitalization was assigned to the symptoms resulting from CHF. According to FRANÇA \& ABREU ${ }^{17}$, the presence of these complications increases therapeutic costs, highlighting the importance of University Hospitals in providing a differentiated care to this group of patients.

The most commonly used therapeutic agents were consistent with the most prevalent clinical form of $\mathrm{CD}$ in the elderly population studied (cardiac form). The main drugs used were found to act in the cardiovascular function, as follows: diuretics (45.4\%), ACEI (36.1\%), $\alpha$ and $\beta$-blockers $(21.6 \%)$ and anticoagulants (21.6\%). The average of three medications per patient was expected, since the elderly, due to accumulation of chronic diseases, comprise the most medicalized group in society ${ }^{19}$.

Polypharmacy is an important issue among the geriatric population, given that the consequence of the wide use of drugs affects their clinical and economic context, impacting on patient safety ${ }^{56}$. Risks related to polypharmacy are higher in the older age group due to the physiological changes resulting from aging (eg.: reduced metabolic capacity of the liver and renal involvement), which lead to an increased incidence of adverse reactions and more serious repercussions which may increase morbidity and mortality $1,8,56$.

It can be concluded, therefore, that the chagasic elderly comprise a vulnerable group of patients that have an association between the risk of morbimortality for Chagas heart disease and the other comorbidities often present in this age group, as well as the risk of drug interactions due to polypharmacy. Since the growth of the chagasic population above 60 years is a reality, this finding should draw the attention of health authorities to improve access to health services as well as the training of qualified professionals in the treatment and recognition of clinical differences inherent to this group of patients.

\section{RESUMO}

\section{Perfil clínico e epidemiológico de pacientes idosos com doença de Chagas atendidos entre 2005-2013 por um serviço de atenção farmacêutica no estado do Ceará, nordeste do Brasil}

Controlando-se a transmissão da doença de Chagas, surge o desafio de prestar assistência a milhões de pacientes infectados que chegam à velhice. Neste estudo, foram avaliados os registros socioeconômicos, demográficos e de comorbidades de todos os pacientes chagásicos idosos acompanhados no Serviço de Atenção Farmacêutica do Laboratório de Pesquisa em Doença de Chagas. As informações relacionadas à forma clínica da doença foram obtidas a partir de registros médicos disponibilizados pelo Hospital Universitário Walter Cantídio. O perfil da população estudada foi de: mulheres (50,5\%); idade média de 67 anos; aposentados $(54,6 \%)$; casados $(51,6 \%)$; alta taxa de analfabetismo (40,2\%); e renda familiar de um salário mínimo (51,5\%). As formas clínicas predominantes da doença de Chagas foram a cardíaca $(65,3 \%)$ e a indeterminada $(14,7 \%)$. As principais alterações eletrocardiográficas foram o bloqueio de ramo direito $(41,0 \%)$, associado ou não ao bloqueio ântero superior esquerdo $(27,4 \%)$. O número médio de comorbidades por paciente foi de $2,23 \pm 1,54$, sendo a hipertensão arterial sistêmica a principal encontrada $(67,0 \%)$. Verificou-se que os idosos constituem grupo vulnerável de pacientes que associam o envelhecimento com as alterações cardíacas e/ou digestivas resultantes da evolução da doença de Chagas e outras comorbidades, o que exige atenção especial dos serviços de saúde para um atendimento médico e social mais adequado.

\section{REFERENCES}

1. Aguiar PM, Lyra JDP, Silva DT, Marques TC. Avaliação da farmacoterapia de idosos residentes em instituições asilares no nordeste do Brasil. Lat Am J Pharm. 2008;27:454-9.

2. Alencar JE. Estudo sobre a epidemiologia da Doença de Chagas no Ceará. III. Região do Baixo Jaguaribe. Rev Bras Malariol Doenças Trop. 1965;17(2-3):149-58.

3. Almeida EA, Neto RMB, Guariento ME, Wanderley JS, Souza ML. Apresentação clínica da doença de Chagas crônica em indivíduos idosos. Rev Soc Bras Med Trop. 2007;40:311-5.

4. Alves RMA, Thomaz RP, Almeida EA, Wanderley JS, Guariento ME. Chagas' disease and ageing: the coexistence of other chronic disease with Chagas' disease in elderly patients. Rev Soc Bras Med Trop. 2009;42:622-8.

5. Bertanha L, Guariento ME, Magna LA, Almeida EA. Caracterização clínico-laboratorial de chagásicos hipertensos sem insuficiência cardíaca manifesta. Rev Soc Bras Med Trop. 2008;41:163-8

6. Borges-Pereira J, Sarquis O, Zauza PL, Britto C, Lima MM. Epidemiologia da doença de Chagas em quatro localidades rurais de Jaguaruana, Estado do Ceará. Soroprevalência da infecção, parasitemia e aspectos clínicos. Rev Soc Bras Med Trop. 2008;41:345-51.

7. Bozelli CE, Araújo SM, Guilherme ALF, Gomes ML. Perfil clinico-epidemiológico de pacientes com doença de Chagas no hospital universitário de Maringá, Paraná, Brasil. Cad Saude Publica. 2006;22:1027-34.

8. Burton DG, Allen MC, Bird JL, Faragher RG. Bridging the gap: ageing, pharmacokinetics and pharmacodynamics. J Pharm Pharmacol. 2005;57:671-9.

9. Carvalho Filho ET, Figueira JC, Pasini U, Forti NA, Curiati JA, Ferreira MC, et al. Aspectos da doença de Chagas no idoso. Arq Bras Cardiol. 1985;45:103-7.

10. Coelho Júnior AMP, Novaes ES, Ferreira E, Neves MAS, Cassini PVS, Duarte TMH et al. Cardiopatia chagásica como principal etiologia de ICC em pacientes internados no HC-UFMG. In: $23^{\circ}$ Reunião Anual de Pesquisa Aplicada em Doença de Chagas, Uberaba, 2007. Resumos.

11. Consenso Brasileiro em Doença de Chagas. Secretaria de vigilância em saúde do Ministério da Saúde. Rev Soc Bras Med Trop. 2005;38(Supl 3):7-29.

12. Coura JR. Chagas disease: what is known and what is needed: a background article. Mem Inst Oswaldo Cruz. 2007;102(Suppl 1):113-22.

13. Coutinho CFS. Fatores associados ao risco para doença de Chagas em área rural do Município de Russas, Ceará, Brasil: abordagem especial. [Dissertação]. Rio de Janeiro: Escola Nacional de Saúde Pública Sérgio Arouca; 2010.

14. Dias JCP. Globalização, iniquidade e doença de Chagas. Cad Saude Publica. 2007;23(Sup11):S13-S22.

15. Dias JCP. O Controle da doença de Chagas no Brasil. In: Silveira AC, organizador. O controle da doença de Chagas nos países do cone sul da América: história de uma iniciativa internacional 1991-2001. Brasília: Organização Pan-Americana de Saúde; 2002. p. $145-250$.

16. Dias JCP, Silveira AC, Schofield CJ. The impact of Chagas disease control in Latin America: a review. Mem Inst Oswaldo Cruz. 2002;97:603-12. 


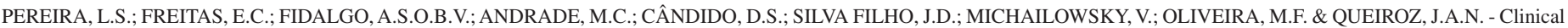
and epidemiological profile of elderly patients with Chagas disease followed between 2005-2013 by pharmaceutical care service in Ceará State, Northeastern Brazil. Rev. Inst. Med. Trop. Sao Paulo, 57(2): 145-52, 2015.

17. França SB, Abreu DMX. Morbidade hospitalar por doença de Chagas no Brasil. Rev Soc Bras Med Trop. 1996; 29:109-15.

18. Freitas EC. Inquérito soroepidemiológico da doença de Chagas no município de Limoeiro do Norte, Ceará, em 2013. [Dissertação]. Fortaleza: Universidade Federal do Ceará, Faculdade de Medicina; 2014.

19. Gontijo MF, Ribeiro AQ, Klein CH, Rozenfeld S, Acurcio FA. Uso de anti-hipertensivos e antidiabéticos por idosos: inquérito em Belo Horizonte, Minas Gerais, Brasil. Cad Saude Publica. 2012;28:1337-46.

20. Guariento ME, Alegre SM, Almeida EA, Wanderley JS. Doença de Chagas e enfermidades associadas em um serviço de referência. Rev Soc Bras Med Trop. 2002;35(Supl 3):206-7.

21. Guariento ME, Alliegro FC, Almeida EA. Doença de Chagas associada a doenças crônicas em pacientes assistidos em ambulatório de hospital universitário. Rev Bras Clin Med 2009; $7: 84-8$

22. Guariento ME, Carrijo CM, Almeida EA, Magna LA. Perfil clínico de idosos portadores de doença de Chagas atendidos em serviço de referência. Rev Bras Clin Med. 2011;9:20-4

23. Guariento ME, Orosz JE, Gontijo JA. Interação clínica entre moléstia de Chagas e hipertensão arterial primária em um serviço de referência ambulatorial. Arq Bras Cardiol. 1998;70:431-4

24. Guariento ME, Ramos MC, Gontijo JAR, Carvalhal SS. Doença de Chagas e hipertensão arterial primária. Arq Bras Cardiol. 1993;60:71-5

25. Gurgel CBFM, Miguel Júnior A, Mendes CR, Zerbini CO, Carcioni TM. Frequência da hipertensão arterial na doença de Chagas: estudo clínico retrospectivo. Arq Bras Cardiol. 2003;81:541-4

26. Higuchi ML, Benvenuti LA, Martins RM, Metzger M. Pathophysiology of the heart in Chagas' disease: current status and new developments. Cardiovasc Res. 2003;60:96107.

27. Ianni BM, Mady C, Arteaga E, Fernandes F. Doenças cardiovasculares observadas durante o seguimento de um grupo de pacientes na forma indeterminada da doença de Chagas. Arq Bras Cardiol. 1998;71:21-4.

28. Instituto Brasileiro de Geografia e Estatística, IBGE. Indicadores sociodemográficos e de saúde no Brasil. Rio de Janeiro: IBGE; 2009.

29. Instituto Brasileiro de Geografia e Estatística, IBGE. Perfil dos idosos responsáveis pelos domicílios no Brasil. Rio de Janeiro: IBGE; 2002

30. Jurberg J, Galvão C, Noireau F, Carcavallo RU, Rocha DS, Lent H. Uma iconografia dos triatomíneos (Hemíptera: Reduviidae). Entomol Vetores. 2004;11:454-94.

31. Kamiji MM, Oliveira RB. O perfil dos portadores de doença de Chagas, com ênfase na forma digestiva, em hospital terciário de Ribeirão Preto, SP. Rev Soc Bras Med Trop. 2005;38:305-9.

32. Kinsella K, Gist YJ. Gender and ageing: mortality and health. [cited 2014 Jan 17] Available from: http://www.census.gov/ipc/prod/ib98-2.pdf

33. Lima-Costa MF, Barreto SM, Giatti L. Condições de saúde, capacidade funcional, uso de serviços de saúde e gastos com medicamentos da população idosa brasileira: um estudo descritivo baseado na pesquisa nacional por amostra de domicílios. Cad Saude Publica. 2003;19:735-43

34. Lima-Costa MF, Barreto SM, Guerra HL, Firmo JOA, Uchoa E, Vidigal PG. Ageing with Trypanosoma cruzi infection in a community where the transmission has been interrupted: the Bambuí Health and Ageing Study (BHAS). Int J Epidemiol. 2001;30:887-93
35. Lima-Costa MF, Guerra HL, Barreto SM, Guimarães RM. Diagnóstico da situação de saúde da população idosa brasileira: um estudo da mortalidade e das internações hospitalares públicas. Inf Epidemiol SUS. 2000;9:23-41.

36. Lima-Costa MF, Peixoto SV, Giatti L. Tendências da mortalidade entre idosos brasileiros (1980-2000). Epidemiol Serv Saude. 2004;13:217-28.

37. Lima-Costa MF, Peixoto SV, Matos DL, Firmo JOA, Uchôa E. Predictors of 10-year mortality in a population of community-dwelling Brazilian elderly: the Bambui cohort study of aging. Cad Saude Publica. 2011;27:360-9.

38. Lima-Costa MF, Uchoa E, Guerra HL, Firmo JOA, Vidigal PG, Barreto SM. The Bambui health and ageing study (BHAS): methodological approach and preliminary results of a population-based cohort study of the elderly in Brazil. Rev Saude Publica 2000;34:126-35.

39. Macêdo VO. Forma indeterminada da doença de Chagas. In: Dias JCP; Coura JR, organizadores. Clínica e terapêutica da doença de Chagas: uma abordagem prática para o clinico geral. Rio de Janeiro: FIOCRUZ; 1997. p. 135-51.

40. Magnani C, Oliveira BG, Gontijo ED. Representações, mitos e comportamentos do paciente submetido ao implante de marcapasso na doença de Chagas. Cad Saude Publica. 2007;23:1624-32.

41. Maia FOM, Duarte YAO, Lebrão ML, Santos JLF. Risk factors for mortality among elderly people. Rev Saude Publica. 2006;40:1049-56.

42. Mathias TA, Jorge MH, Laurenti R. Cardiovascular disease in the elderly: analysis of the behavior of mortality in a municipaliity in the Southern Region of Brazil from 1979 to 1998. Arq Bras Cardiol. 2004;82:533-50.

43. Medeiros-Souza P, Santos-Neto LL, Kusano LTE, Pereira MG. Diagnosis and control of polypharmacy in the elderly. Rev Saude Publica. 2007;41:1049-53.

44. Netto JCA, Mello JV, Barbosa W. Doença de Chagas. Correlação sorológica e eletrocardiográfica em grupos de indivíduos idosos. Rev Soc Bras Med Trop. 1970;4:75-82.

45. Oliveira FA, Reis MA, Teixeira PA. A cardiopatia chagásica em idosos necropsiados Rev Soc Bras Med Trop. 2001;34(Supl 3):161-2

46. Oliveira FAS, Bicalho GVC, Souza-Filho LD, Silva MJ, Gomes Filho ZC. Características epidemiológicas dos pacientes com Doença de Chagas. Rev Bras Med Família Comunidade. 2006:6:107-13.

47. Oliveira MF, Nagao-Dias AT, Pontes VMO, Souza Júnior AS, Coelho HLL, Coelho IC Tratamento etiológico da doença de Chagas no Brasil. Rev Patol Trop. 2008;37:209

48. Papaléo-Netto M, Yuaso DR, Kitadai FT. Longevidade: desafio no terceiro milênio. Mundo Saúde. 2005;29:594-606.

49. Pereira-Barretto AC, Arteaga E, Mady C, Ianni BM, Bellotti G, Pileggi, F. Sexo masculino: fator prognóstico na doença de Chagas. Arq Bras Cardiol. 1993;60:225-27.

50. Piancastelli CH. Colopatia chagásica. In: Gontijo ED; Rocha MOC, organizadores Manejo clínico em doença de Chagas. Brasília: Fundação Nacional de Saúde; 1998.

51. Pilger C, Menon MH, Mathias TAF. Características sociodemográficas e de saúde de idosos: contribuições para os serviços de saúde. Rev Lat Am Enfermagem. 2011;19:1230-8

52. Rassi A Jr, Rassi A, Little WC, Xavier SS, Rassi SG, Rassi AG, et al. Development and validation of a risk score for predicting death in Chagas' heart disease. N Engl J Med. 2006;355:799-808.

53. Rassi A Jr, Rassi A, Rassi SG. Predictors of mortality in chronic Chagas disease: sistematic review of observational studies. Circulation. 2007:115:1101-8. 
PEREIRA, L.S.; FREITAS, E.C.; FIDALGO, A.S.O.B.V.; ANDRADE, M.C.; CÂNDIDO, D.S.; SILVA FILHO, J.D.; MICHAILOWSKY, V.; OLIVEIRA, M.F. \& QUEIROZ, J.A.N. - Clinical and epidemiological profile of elderly patients with Chagas disease followed between 2005-2013 by pharmaceutical care service in Ceará State, Northeastern Brazil. Rev. Inst. Med. Trop. Sao Paulo, 57(2): 145-52, 2015.

54. Rocha MO, Teixeira MM, Ribeiro AL. An update on the management of Chagas cardiomyopathy. Expert Rev Anti Infect Ther. 2007;5:727-43.

55. Ruijter W, Westendorp RGJ, Macfarlane PW, Jukema JW, Assendelft WJJ, Gussekloo J. The routine electrocardiogram for cardiovascular risk stratification in old age: the Leiden 85-plus study. J Am Geriatr Soc. 2007;55:872-7.

56. Secoli SR. Polifarmácia: interações e reações adversas no uso de medicamentos por idosos. Rev Bras Enferm. 2010;63:136-40.

57. Silva EM, Rocha MOC, Silva RC, Paixão GC, Buzzati H, Santos NA, et al. Estudo clínico-epidemiológico da doença de Chagas no distrito de Serra Azul, Mateus Leme, centro-oeste do Estado de Minas Gerais. Rev Soc Bras Med Trop. 2010;43:178-81.

58. Silva SA, Gontijo ED, Amaral CFS. Case-control study of factors associated with chronic Chagas heart disease in patients over 50 years of age. Mem Inst Oswaldo Cruz. 2007; 102:845-51.

59. Silveira AC. Os novos desafios e perspectivas futuras do controle. História sobre a doença de Chagas no Brasil. Rev Soc Bras Med Trop. 2011;44(Supl 2):122-4.
60. Steinman MA, Rosenthal GE, Landefeld CS, Bertenthal D, Sen S, Kaboli PJ. Conflicts and concordance between measures of medication prescribing quality. Med Care. 2007;45:95-9.

61. Veras RP. Modelos contemporâneos no cuidado à saúde: novos desafios em decorrência da mudança do perfil epidemiológico da população brasileira. Rev USP. 2001;51:72-85.

62. World Health Organization. Chagas disease: control and elimination. Geneva: WHO/ EB124/17; 2008 .

63. World Health Organization. Consultation on International Biological Reference Preparations for Chagas diagnostic tests. Geneva: WHO; 2007. [cited 2013 Dec 19]. Available from: http://www.who.int/bloodproducts/ref_materials/WHO_Report_1st_ Chagas_BRP_consultation_7-2007_final.pdf

64. Zaslavsky C, Gus I. Idoso: doença cardíaca e comorbidades. Arq Bras Cardiol. 2002;79:635-9.

Received: 11 March 2014

Accepted: 21 July 2014 